Article received on October $6^{\text {th }} 2019$

Article accepted on November $28^{\text {th }} 2019$

UDC: 78(474.5)

$78(438)$

\title{
Rūta Stanevičiūtè*
}

Lithuanian Academy of Music and Theatre

\section{LITHUANIAN AND POLISH MUSICAL NETWORKING DURING THE COLD WAR: POLITICAL CURTAINS AND CULTURAL CONFRONTATIONS ${ }^{1}$}

\begin{abstract}
Poland and Lithuania at the end of the Cold War serve as a case study for the theorization of music and politics. In this article, a little-studied field of two neighbouring countries' cultures has been chosen: oppositional musical networking, that in addition resulted in politically and socially engaged collaboration between Polish and Lithuanian musicians since late 1970s.

Basing on the concept of a transformative contact (Padraic Kenney 2004), the author reflects on the factors which predetermined the intercommunication of informal communities in mentioned countries in the years of ideological and political constraints and the ways in which such relationships contributed to the cultural and political transformation of societies. Through the interactions of the milieus of the Polish and Lithuanian contemporary music, the participation of the norms and representations of one culture in the field of the other culture is discussed. The author shows that the paradoxical constraints on the informal relations between Lithuanian and Polish musicians were strongly affected by the political relations between the USSR and the Polish People's Republic, especially in the wake of the intensification of political resistance to the imposed Communist regime in Poland.
\end{abstract}

Keywords: Music and politics; oppositional cultural networking; transnational diffusion; Polish-Lithuanian musicians' collaboration; Cold War; identity (trans)formation.

\footnotetext{
* Author contact information: ruta.staneviciute@gmail.com

1 This article is a part of the project "Music of Change: Expression of Liberation in Polish and Lithuanian Music Before and After 1989" (Nr. P-LL-18-213), funded by the National Science Centre (Poland) and Lithuanian Research Council (Lithuania).
} 


\section{Introduction}

In recent decades, when critically reviewing the interpretations of the Soviet era or, more specifically, the Cold War processes, researchers in the history of the USSR and the Communist bloc countries have been intensively debating the issues of informally related communities and social and cultural networks. ${ }^{2}$ Although the research tended to more frequently focus on the phenomena of a single country and their impact on the political and social transformation of societies, informal relationships and cultural exchanges based on them have been of an increasing interest to researchers dealing with transnational processes. What predetermined the communication of informal communities from different countries in the years of ideological and political constraints? How did the exchange of information, people, and ideas between the cultures of different countries take place through informal channels? Simo Mikkonen and Pia Koivunen who analysed the specifics of cultural communication and exchanges between the Western and Eastern countries, separated by the ideological tension of the Cold War, noted that the traditional comparative approaches, based on a systematic study of differences and similarities between societies or cultures, were not sufficient there. The Finnish researchers linked the change in the comparative perspective to the concepts of transfer and translation, enabling one to consider how the norms and representations of one culture participated in the field of another culture. ${ }^{3}$

Going beyond purely transnational cultural interactions, American historian Padraic Kenney emphasised the need for a more in-depth discussion of the concept of a transformative contact, conducive to more dynamic comparativism. Kenney noted that transnational dissemination processes were a relatively new field of social research and identified six categories of importance for transformative contacts: command; text; legend; pilgrimage; courier; and convocation. ${ }^{4}$ Importantly, Kenney modelled the said typology to

2 In Lithuania, the most comprehensive research on informal relationships-based networking in the Soviet era was conducted by a team of scholars brought together by sociologist Ainè Ramonaitè. Cf. Nematoma sovietmečio visuomene [The Invisible Society of the Soviet Era], Ainè Ramonaitè (Ed.), Vilnius, Naujasis židinys-Aidai, 2015.

3 Simo Mikkonen, Pia Koivunen, "Introduction: Beyond the Divide", in: Simo Mikkonen, Pia Koivunen (Eds), Beyond the Divide. Entangled Histories of Cold War Europe, New York, Oxford, Berghahn, 2015, 11-12.

4 Padraic Kenney, "Opposition Networks and Transnational Diffusion in the Revolutions of 1989”, in: Padraic Kenney, Gerd-Rainer Horn (Eds), Transnational Moments of Change: Europe 1945, 1968, 1989, Lanham, MD, Rowman \& Littlefield, 2004, 207-208. 
examine the processes of resistance and transformation in the communist countries of Eastern and Central Europe through the analysis of the origins of the 1989 revolutions. The first category of command, or impulse, was specifically explained by him with examples from the 1989 revolutions, however, it could be more broadly defined as a response to political or societal events (the Soviet perestroika, debated by Kenney, could be supplemented with more examples, such as the political Solidarity movement in Poland, the Lithuanian Reform Movement Sajüdis, the introduction of the martial law regime in Poland, the fall of the Berlin Wall, etc.). The category of text was associated by Kenney with dissident activities, samizdat publishing, and high-impact publications (such as by Václav Havel's essay The Power of the Powerless, 1978) or other broad-resonance cultural artifacts. The categories of legends and pilgrimage, interrelated in a specific way, highlighted the importance and use of cultural memory and the power of intercultural attraction of cities and artistic events. Individuals (couriers), promoting transnational networking and collaboration, inspired festivals, conferences, and other events (convocations or meetings), thus enhancing the expression of liberation. Kenney argued that every form of contact - command or text, legend or courier, etc. - functioned in two ways: actually and symbolically. For a transnational contact to boost transformation (of a relationship or a self-image), real events, cultural artifacts, or actions of individuals had to acquire a symbolic meaning. In non-democratic regimes, every real action of transnational networking - "crossing a border, holding a conference, even reading a foreign text or listening to Radio Free Europe - was a symbolic act, too" that changed the geography of the living world. ${ }^{5}$

Kenney's typology was conducive to the discussion of the transnational contacts and exchanges of Lithuanian musicians in the late Soviet era that were forged and developed through informal channels. From Steven Vertovec's point of view, transnational exchanges were particularly strongly affected by informal relationships between non-governmental institutions and cultural actors which more fundamentally revealed the nature of cultural transfer and translation. ${ }^{6}$ Peter J. Schmelz also noted insufficient attention of researchers to informal relationships between the Soviet and Western musicians - so far, emphasis had been placed on intercultural diplomacy and mu-

5 Padraic Kenney, op. cit., 221.

6 Steven Vertovec, Transnationalism, London and New York, Routledge, 2009, 3. 
sical exchange developed at the governmental level. ${ }^{7}$ It was in the late Soviet era that transnational informal contacts became a phenomenon which transformed the self-image and international reception of the field of contemporary Lithuanian music. The institutional structure of the Soviet musical culture resulted in the situation when informal relationships and channels were of particular concern to composers and musicologists, severely constrained by two opposing features of the cultural system - the centralized international dissemination of their works and an underdeveloped institutional network of contemporary music. Through the research perspectives implied by the typology of transformative contacts, the article seeks to identify the place occupied in the transnational relationships by close neighbourhood relations during the period in question, which had seldom been in focus of international research. ${ }^{8}$ For a more comprehensive analysis, the informal relationships between Lithuanian and Polish musicians at the end of the Cold War were chosen, because it was during that period that they became particularly intense and involved a number of prominent figures on the music scene in both countries.

\section{Political and cultural stagnation as an impetus for change}

In his 1975 review of the Warsaw Autumn Festival, Krzysztof Droba, a Polish musicologist who had then just made his debut in music criticism, wrote:

Contrary to the domains of literature, art, or theatre, no unique artistic generation emerged in musical life. In scanty debutes of the Autumn, I do not find any signs of artistic thinking. After all, the artistic and life experience of professors is different from that of their students. A composer making his debut in 1970s tends to forget that. Therefore, his performance is not authentic - he never stops to consider what was said before him or what he himself would like to say. The current year can be called a period of debutant pupils: immature, dependent on others, and false personalities. ${ }^{9}$

\footnotetext{
7 Peter J. Schmelz, "Intimate Histories of the Musical Cold War: Fred Prieberg and Igor Blazhkov's Unofficial Diplomacy”, in: Jessica C.E. Gienow-Hecht (Ed.), Music and International History in the Twentieth Century, New York, Berghahn, 2015, 191-192.

8 In recent years, the theme in question has been especially intensely studied by Peter J. Schmelz, developing the project Complex Webs: Unofficial Musical Exchange between Russia, Ukraine, and West Germany during the Cold War.

9 Krzysztof Droba, "Z myślą o przyszłej Jesieni [With a View to Future Autumn]”, Ruch muzyczny, 25, 1975, 15.
} 
Lithuanian composer Giedrius Kuprevičius brought similar impressions from the 1977 Plenary Session of the USSR Composers' Union in Moscow dedicated to the work of young composers:

Strangely enough, quite a few young composers write very traditional music. In terms of both expressive means and themes, that music does not go beyond the general level of the fifties or sixties. Blank instrumentation, cold academic forms, colourless emotions, and pseudo-philosophic posturing prompt passivity. Surprisingly, after the performance of such a composition, a very young composer comes on the stage. That reminds of the words of Aram Khachaturian at the opening of the plenary session: "Write as you please, use whatever you like, only make us feel that the music was written by a young, passionate, and talented composer." 10

Warsaw and Moscow were two opposing axiological musical centres of the Socialist Commonwealth countries, two representations of contemporary music with radically opposite goals, however, the critical opinions that reflected them could be seen as symptomatic responses to the signs of ideological and cultural stagnation in the communist world. From a historical distance, researchers on the then Lithuanian art processes noted that the first signs of stagnation were revealed already in the years 1969 through $1970 .{ }^{11} \mathrm{In}$ the Lithuanian music culture, the self-image of stagnation became more evident in the period of 1972 to 1974: the number of events and articles of music criticism decreased, and trends of creative inertia began to be recorded in the critical discourse. ${ }^{12}$ Sociopolitical processes influenced the feeling of stagnation and cultural censorship: events of political and social resistance (such as the Prague Spring 1968, workers' strikes and demonstrations in 1970 in Poland, etc.) were accompanied by campaigns initiated by the communist regimes to suppress the expression of liberation. Between the 1960s and 1970s,

10 Giedrius Kuprevičius, "Jaunųjų kūrybos pasiklausius [Upon Listening to Compostions of the Youth]", Kauno tiesa, 26. 03. 1977. In the review, Kuprevičius noted that, during the plenary session, the greatest attention was attracted by Russian composers' rock operas and the first use of a synthesizer in Soviet pop music (in David Tukhmanov's record The Wave of my Memory), although he described them as examples of low music culture.

11 Cf. Jolita Mulevičiūtè, "Atsinaujinimo sąūdis lietuvių tapyboje 1956-1970 m. [Renewal Movement in Lithuanian Painting in 1956-1970]", in: Žmogus ir aplinka XX a. Lietuvos daileje, Vilnius, Academia, 1992, 189.

12 Cf. Rūta Naktinytè, "Inertiškumo simptomai? [Symptoms of Inertia?]", Literatūra ir menas, 30. 11. 1974. 
the increased 'witch-hunt' of political dissidents in Lithuania, the struggle of the Soviet authorities against the oppositional underground activities of the Catholic Church, and the Russification of culture after the self-immolation of young dissident Romas Kalanta in 1972 left an imprint on cultural practices. Those activities of political restraint were further strengthened by the 1972 Resolution of the Central Committee of the Communist Party of the Soviet Union on literary and art criticism, triggering a new wave of constraints on, and censorship of, music criticism.

It was, however, during that period of stagnation of cultural expression that significant changes in the artistic self-image occurred, which should be seen as signs of a shift already made and the start of the new beginnings. That was particularly evident in the milieu of Lithuanian musicians through the change in geo-cultural identities. After 1970, the cultural optics changed radically: Lithuanian composers no longer sought unconditional authorities behind the Iron Curtain, although no stronger cultural isolationism existed, either. Like in the previous decade, music pilgrims of the 1970s were flocking to the Warsaw Autumn Festival to hear newer music, and contemporary Western music, also performed not merely by local musicians, was increasingly frequently performed on the Vilnius concert stages. The information about topical phenomena was supplemented by music recordings, brought from abroad, and the broadcasts of foreign radio programmes. Through them, minimalism and European and the US experimental music became popular quite early in Lithuania, with American John Cage becoming almost a cult figure, while some composers sought counterbalance for the faded post-war avant-garde fame in the works of French composer Olivier Messiaen. In that way, a heterogeneous picture of international contemporary music as a context for the inspirations and interpretations of the works of Lithuanian composers started to form, although it was quite distant from the earlier identifications with the imaginary West avant-garde both in content and character.

In his influential monograph on the late Soviet era, Alexei Yurchak identified the imagined West as a powerful myth flourishing in the Soviet self-awareness in various forms, pervading both cultural expression and everyday activities. ${ }^{13}$ Contrary to the everyday life, where the demand for Western goods and their imitations kept growing, the power of the imagi-

13 Алексей Юрчак, Это было навсегда, пока не кончилось. Последнее советское поколение, Москва, Новое литературное обозрение, 2014, 313-314. According to author, through the imaginary West, the Soviet subject formed himself. (Ibid., 386). 
nary West with regard to artistic practices was diminishing in the years of the Soviet stagnation. Similar changes in the self-image were also characteristic of the neighboring Soviet republics: thus, e.g., Russian musicologist Tatyana Cherednichenko wrote about the period of 1974 through 1978 as the true beginning of the 1970s, a tectonic break in which seemingly undeniable truths based on the history of modern European composition were already slipping out of hand. Not limiting her story to Russian music, Cherednichenko attributed yesterday's avant-gardists to contemporary sibeliuses ("avant-garde academicism") or kabalevskies ("the garbage of contemporary music"), while she considered Alfred Schnittke, Sofia Gubaidulina, or Krzysztof Penderecki, inspirators of the Eastern European avant-garde of the 1960s, to have become prestigious part of the contemporary music festivals. ${ }^{14}$

When critically exploring the changes in the creative landmarks of Lithuanian composers during the Soviet era, composer and music critic Šarūnas Nakas aptly noted that, "in the 1970s, the natural attraction of several centres formed. They were all outside Lithuania $<\ldots>-$ Warsaw, Tallinn, Moscow as well as Kiev and Riga". ${ }^{15}$ Nakas believed that the change in attraction centres was driven by two reasons: first, over the previous decades, no genuine relationships had been forged with the mythologized Western centres which could have guaranteed the international dissemination of Lithuanian music and due attention to it, and, second, dissatisfaction with the "transplantation of fashionable Western styles into the local milieu" and aspirations to "create a full-blooded world of Lithuanian music". ${ }^{16}$ However, the "geographic turn" of Lithuanian music in the 1970s should not be related merely to the transformation of the subjective creative orientations of several generations of composers at that time or the restrictions on more intense dissemination of their music. It is also noteworthy that, during the period in question, due to the commercialisation of the Soviet export of music, tours of Lithuanian musicians stretched far to the West and East, even though limited by ideological or conjunctural solutions. On the other hand, the problem of a cultural dialogue and the understanding of compositions during the decade in question

14 Татьяна Чередниченко, Музыкальный запас. 70-е. Проблемы. Портреты. Случаи [Musical Resources. The 1970s. Problems. Portraits. Cases.], Москва: Новое литературное обозрение, 2002, 9, 17-18.

15 Šarūnas Nakas, "Kelionè be kelio, nes veidrodis be atspindžio [Travel with no Road, because of the Mirror without Reflection]". Access online: http://www.modus-radio. com/eseistika/kelione-be-kelio [viewed on 05. 06. 2019].

16 Ibid. 
was also faced by the Soviet composers whose music received abundant performances and attracted a new wave of strong interest in the West. Thus, according to Levon Hakobian, arrogance and disdainful attitudes were frequent in reviews of Western music critics of the USSR's broad-resonance non-conformist music festival in Cologne (spring 1979) or concert programmes at the Paris-Moscow Exhibition (1979); while the reviews of Soviet music published between the 1970s and 1980s abounded in banal descriptions and factual errors. ${ }^{17}$

Therefore, when exploring what kind of transnational aspirations and relationships were forming in the Lithuanian music scene during the years of the late Soviet stagnation, it is useful to consider broader changes in the cultural self-image. To contextualise the caesura between the Soviet Thaw and perestroika, Pierre Bourdieu's anthropological analysis of conversation is to be employed, which defines discursive practices as the modalities of different systems of self-image and modus operandi. In the Soviet period, the outward-oriented discourse of modernisation (the search for "windows of ideas", external sources of the musical tradition updating, and new resources for the language of music), fueled by political liberalisation (the Thaw), became exhausted in the mid-1970s. Based on Bourdieu's terminology, the new expression (from the mid-1970s) can be described as a discourse of familiarity ("the spirit of co-existence"), as opposed to the previous outward-oriented discourse. ${ }^{18}$ The discourse of familiarity is defined here as an imagined commonality of values, cultural codes, and experiences of the local or native world, which is as if taken for granted and does not require further explanation. Such a modus operandi indirectly correlates with the concept of close communication, explored by Alexei Yurchak ${ }^{19}$ : according to him, it is a special affective "space" that defines the deep and intense inter-subjectivity of the late-Soviet era. In this way, in the 1970s shift in the self-image of musicians, artistic, moral, and social attitudes intertwined, which enabled the interrelationships of the community of musicians and their transnational contacts.

17 Levon Hakobian, “The Reception of Soviet Music in the West: a History of Sympathy and Misunderstanding", Musicology, 13, 2012, 132-133.

18 See Pierre Bourdieu, Outline of a Theory of Practice, Cambridge, Cambridge University Press, 1977, 18.

19 Алексей Юрчак, ор. cit., 296. 


\section{Meeting places in the mix of formal and informal musical life}

Since the 1960s, Lithuanian performers increasingly frequently performed in Poland under the Soviet Concert Agency (Goskoncert) and the Polish Art Agency (PAGART) exchange agreements, and they would include national music in their programmes. Therefore, it sounded paradoxical when some Polish musicians claimed that, for several decades after the war, Lithuanian music was unknown in Poland: "more was known about, for example, Polynesian music than that of neighbouring Lithuania". ${ }^{20}$ Were there any other reasons for not to have heard it, although it was actually performed? Back in 1975, Krzysztof Droba, who accidentally met with Lithuanians at a typical Soviet culture promotion event in Krakow, eventually became the most consistent promoter of Lithuanian music in Poland, arguing that, until then, the image of the neighbours' music was shaped solely by official exports:

At that time, Lithuania could only exist to the extent it occupied in the culture of the Soviet Union - as one of the republics, it could have representatives at international events, and those often had nothing to do with true values. After all, people with 'good reputation' were going abroad: social activists, the bureaucratic elite, presidents of the art unions, but not some talented non-conformists. In the past, the music was imposed on us that had been approved by Moscow. ${ }^{21}$

It was in 1975 that Droba began organising independent festivals in small Polish towns (Stalowa Wola, Baranów, Sandomierz), designing them as an opposition to the formal life of contemporary music and to the Polish Composers' Union of which he was not yet a member. In that respect, until the late 1980s, the situation in neighbouring Poland was very different from that of the USSR: despite the ideological and administrative control, organisations outside the official network of cultural institutions could operate there, such as the Polish Contemporary Music Society (Polskie Towarzystwo Muzyki Współczesnej $)^{22}$ which had suspended its activities only for a short post-war

20 "A zaczeło się - od Festiwali w Stalowej Woli. Z Krzysztofem Drobą rozmawia Alwida Rolska [It Began from the Festival in Stalowa Wola. Alwida Rolska Interviews Krzysztof Droba]", Kurier Wileński, 27. 11. 1990, 6.

21 "Naujasis romantizmas, Lietuva ir kontrabanda. Łukaszas Tischneris kalbasi su Krzysztofu Droba [The New Romanticism, Lithuania and Smuggling. Łukasz Tischner Interviews Krzysztof Droba]", in: Krzysztof Droba, Susitikimai su Lietuva, Rūta Stanevičiūtè (Ed.), Vilnius, Lietuvos kompozitorių sajunga, Lietuvos muzikos ir teatro akademija, 2018, 79.

22 The organisation was the Polish Section of the International Society for Contemporary Music (ISCM), founded in 1924. 
period, or private festivals could be held, such as the Contemporary Music Festivals initiated by Krzysztof Penderecki at his private estate in Lusławice in 1980. Lithuanian musicians, like their colleagues from the USSR cities of Riga, Tallinn, or Kiev which became the new centres of attraction, did not have an opportunity to escape from the official institutional network in the public space. However, it was in the second half of the 1970s that local groups of musicians, related through informal contacts, began to seek opportunities for more active public concert activities and other events not only through official composers' unions, but also through other institutions, such as Komsomol structures, higher schools, or artistic organizations. Characteristically, in the second half of the 1970s and later, those unspecified spaces beyond official culture produced premieres of such emblematic works as Bronius $\mathrm{Ku}$ tavičius' oratorio The Last Pagan Rites (premiered in the Small Baroque Hall in Vilnius in 1978) or Arvo Pärt's Tabula Rasa (premiered in Tallinn Polytechnic School in 1977).

In the late Soviet period, composers and musicologists of Lithuania and the neighbouring countries were forging informal contacts, seeking to distance themselves from the semiofficial life of contemporary music culture and the calendrical rhythm of congresses and plenary sessions of composers' unions. However, until the mid-1980s, no independent festivals featuring not only local, but also foreign music and performers were held in Lithuania, therefore it would be inaccurate to talk about the informal life or institutions of contemporary Lithuanian music. Although the studies of the history of Lithuanian art in the Soviet era have long since abandoned the binary oppositions of formal/informal, conformist/nonconformist, etc., research in informal relationships encourages a critical revision of the established conceptions of the application or rejection of that division. In such a context, the discussion on the values-based and institutional divides in the Soviet field of culture was given a great impetus by Alexei Yurchak's book Everything Was Forever, Until It Was No More (2006). ${ }^{23}$ Rejecting the binary division of the late Soviet reality (state/society, oppression/resistance, formal culture/counterculture, public/private, lie/truth, conformism/non-conformism, etc.), American anthropologist Yurchak inserted the predominant apolitical stance of the majority as a way of 'being outside' the system between the ideological discourse and an openly opposing dissident course of action. In his opinion, that kind

23 First edition in English: Alexei Yurchak, Everything Was Forever, Until It Was No More. The Last Soviet Generation, Princeton and Oxford, Princeton University Press, 2006. 
of positioning typical of the late Soviet period (to get out of the horizons of official ideology and to be invisible to the Soviet system) could not be considered as a non-Soviet existence - rather a symbiosis of the 'non-Soviet worlds' and the Soviet system. ${ }^{24}$ Despite the broad resonance, Yurchak's concept attracted a lot of criticism - musicologists also joined the discussion. American musicologist Peter J. Schmelz, who had most comprehensively considered Yurchak's interpretations of the 'existence outside', sharply criticised the excessively broad and inaccurate Late Soviet era periodisation (1953-1991), which did not take into account the specifics of different historical periods and cultural spheres. ${ }^{25}$ Schmelz also opposed the justification for the possibility of change: significant turning points in the life of the USSR were explained in Yurchak's book by the dynamic interaction between the stability of the norms, values, and rituals of the Soviet life and the internal shifts and displacements in the system, however, the Soviet music transformations did not correlate with the performative reproduction of the unchanging authoritative forms indicated by Yurchak. ${ }^{26}$

Be that as it may, the scholarly debate on the impossibility of drawing a clear dividing line between the official and unofficial fields of culture provoked by Yurchak's book encouraged more careful consideration of the expression of discursive and institutional opposition in different periods of the Soviet era. Without going into broader considerations, we shall note that, in the years of the political Thaw and early stagnation, the meanings of opposition tended to be looked for in the language of music itself. The institutional context of the dissemination of creation became more important in the late Soviet era, after 1970, seeking to establish a symbolic distance from the formal life of contemporary music. Of course, the divide between the formal and the informal contemporary music life (especially in Lithuania, with its absence of an alternative institutional network) were rather imaginary modi operandi. However, the migration of public concerts, meetings, and debates from specialised formal cultural spaces to institutional peripheries with a non-specific function as well as the organisation of contemporary music

24 Алексей Юрчак, op. cit., 257-258, 399.

25 Peter J. Schmelz, Such Freedom, If Only Musical: Unofficial Soviet Music during the Thaw, Oxford, Oxford University Press, 2009, 17-18, see also "What Was 'Shostakovich', and What Came Next?" by the same author in: Journal of Musicology, 24/3, 2007, 301-303.

26 Alexei Yurchak, op. cit., 295. 
festivals in provincial towns of Poland or Lithuania formed as consistent strategies. ${ }^{27}$ As a result, in the long run, not only metropolises of creativity and major prestigious festivals of contemporary music became objects of intercultural pilgrimage: their prestige was also becoming overshadowed by small centres of attraction, enriched by privacy and informal contacts. When drawing the divide between the events of formal and informal musical life both in the cases of Poland and Lithuania, the divide between censored and uncensored activities would be more appropriate. Differently from Poland, where the preconditions for uncensored events formed in the 1960s and 1970s, a favorable environment for them in Lithuania emerged only after the announcement of the Soviet perestroika. In any event, the Polish organisers of independent festivals said they had not been bound by any restrictions on artistic programmes. ${ }^{28}$

\section{Borders, couriers and smuggling}

The press of the 1970s boasted that the tours of the Vilnius String Quartet reached already the African continent. ${ }^{29}$ Even more impressive was the geography of the Lithuanian Chamber Orchestra's concert tours (especially when collaborating with Russian musicians), which may have given the impression that, despite ideological constraints, the international dissemination of Lithuanian music was less restricted by Soviet regime than that of other cultural spheres. However, not all intercultural contacts and cooperation initiatives went smoothly and without external barriers. From that point of view, the informal relations between Lithuanian and Polish musicians in the late Soviet period were forming in a most paradoxical way. Droba, who was an active mediator between Lithuanian and Polish contemporary music milieus, argued that Polish contacts with its eastern neighbours were always acquiring a political tint, since "every [cultural act] was observed and commented upon. The Russian Embassy would protest against totally ridiculous things,

27 Typical Lithuanian examples included the Days of Youth Chamber Music, organized by the Youth Section of the Lithuanian Composers' Union since 1985, independent festivals of happenings held outside of Vilnius since 1988, etc.

28 "Dar od losu. Krzysztof Droba w rozmowie z Kingą Kiwalą [Gift of Fortune. Kinga Kiwala Interviews Krzysztof Droba]", Teoria muzyki. Studia, interpretacje, dokumentacje. Pismo Akademii Muzycznej w Krakowie, IV/6, 2015, 128-129.

29 Donatas Katkus, "Vilnius groja Afrikai [Vilnius Plays for Africa]", Gimtasis kraštas, 10. 02.1977. 
thus providing them with a status of political events." ${ }^{30}$ Restrictions on cultural cooperation became especially strong in the first half of the 1980s due to certain events in Poland, such as the political Solidarity movement, due to which the martial law regime was introduced between 1981 and 1983, as well as the stance of Pope John Paul II on the USSR. During the period of political changes, the above mentioned barriers were remembered with romantic pathos ("it was real underground struggle" 31 ); authentic documents of the period (private correspondence and archival materials of the institutions of the USSR and the Polish People's Republic) testified to quite a number of prohibitions and blockages unsubstantiated by convincing arguments. The 1980-1990 correspondence of Droba with Lithuanian musicologist Vytautas Landsbergis and composer Feliksas Bajoras abounded in considerations how to get permission to come to one or another event or festival, to get academic internships, etc., and how to overcome real or imaginary obstacles. Occasionally, even unrealistic initiatives were undertaken: thus, more than one attempt was made to ask Penderecki, who often gave concerts in Moscow or Leningrad, to intercede with the Chairman of the USSR Composers' Union and the most influential Soviet music functionary Tichon Khrennikov. ${ }^{32}$ The trips of Polish musicians to events held in Lithuania were organised through the Polish Composers' Union or the Ministry of Culture of the PPR, however, the visits of guests had to be approved by the central authorities of the USSR through sending them a personal invitation.

Irrational trip organisation procedures constrained Lithuanian musicians even to a greater degree, therefore quite a few visits of Lithuanian composers Bronius Kutavičius, Feliksas Bajoras, and Osvaldas Balakauskas as well as Lithuanian performers and musicologists to contemporary music festivals in Poland in the first half of the 1980s took place through private invitations. The uncertainty of the exchange system could be illustrated by the circumstances of the Vilnius String Quartet participation in the 1980 Lusławice Festival. Although the Quartet performed extensively on international stages and their tour was organized through the mediation of the Polish TVR, the USSR Goskoncert refused to officially send the ensemble - a telegram reported the

\footnotetext{
30 “Naujasis romantizmas, Lietuva ir kontrabanda..., op. cit., 82.

31 Ibid.

32 Krzysztof Droba's letter to Vytautas Landsbergis, 21. 03. 1982. Vytautas Landsbergis private archive.
} 
performers' being ill. ${ }^{33}$ Another ensemble, the Silesian String Quartet, was invited to perform a composition by Eugeniusz Knapik, commissioned for the festival, which was to have been played by the Vilnius musicians. However, the Vilnius Quartet performers, who arrived as distant relatives ('cousins') of Penderecki at his personal invitation, were able to compete with the Polish colleagues in the interpretation of the double premiere. ${ }^{34}$

Censorship, which restricted the exchange of literature, music compositions, and recordings between the USSR and foreign countries, also lacked any clearer criteria. If the performances of the works of Lithuanian composers were organised through informal channels, it was not always possible to send the sheet music or recordings legally. Moreover, because of the political tensions between the USSR and Poland, parcels and travellers were carefully checked:

I used to transport books that were usually taken away on the border in Grodno. But that's not all! After all, there was always one suitcase or bundle that remained uninspected. Those were mostly underground Solidarity publications, books by Czesław Miłosz, Stefan Kisielewski, and priest Tischner - that was the repertoire of those times. I carried back, for example, letters from Vytautas Landsbergis to Lech Wałęsa. Still, letters were easier to transport, while journals and books were, as a rule, taken away from me. Once I lost a whole yearly set of Tygodnik Powszechny, but was allowed to keep [Czesław Miłosz's] The Valley of Isa, because I swore I was taking it for children. The bird on the cover did not look suspicious, and the Belarussian customs tsarina was finally convinced. Records used to be taken away as well. At that time it was necessary to have permission for the transporting of each and every cassette. ${ }^{35}$

From a historical perspective, not only the well-known practice of Soviet censorship was important but also the cultural horizons shared by networks of musicians linked through informal relationships. Sharing professional literature, music sheets, and recordings was not a new phenomenon - the prerequisites for that emerged in the years of the Soviet Thaw. In the late Soviet era, the culture of sharing in the milieus of musicians became more active, yet

33 V. Kokonin's (Goskoncert) telegram to PAGART, 03. 07. 1980. Russian State Archive for Literature and Art (RGALI), fond 3162, op. 2, ye. kh. 1462.

34 Composer Eugeniusz Knapik remembered the performances in question as two radically different interpretations. See Krzysztof Droba, Spotkania z Eugeniuszem Knapikem [Meetings with Eugeniusz Knapik]. Katowice, Akademia Muzyczna im. Karola Szymanowskiego w Katowicach, 2011, 43.

35 "Naujasis romantizmas, Lietuva ir kontrabanda..., op. cit., 82. 
it had its own specifics. Based on the correspondence of both Lithuanian and Polish musicians and the data of the correspondence with other musicians of Western and Eastern European countries, one can argue it was mainly professional material, literature on art, fiction, and albums that were exchanged. Books by Czesław Miłosz, publications of Polish emigration and Vatican, and periodicals frequently traveled from Poland to Lithuania. It was extremely rare for samizdat or underground literature to be sent in parcels or personally transported, and then only from Poland to Lithuania. However, that did not mean that informal music communities were overtly apolitical or neutral with regard to the ideological discourse. On the contrary, it was specifically in the 1970s and 1980s that the private correspondence between musicians abounded in ironic hints and comments on political events and processes, witty observations on the ideological grimaces of the late stagnation, and insightful perceptions of societal change. In that respect, the letters of Lithuanian and Polish musicians differed significantly from other items of foreign correspondence, in which political topics were mostly avoided.

The colleagues' moral stance on the political and cultural regime was important for the relationships between Lithuanians and Poles. Mieczysław Tomaszewski, spiritus movens of the Musical Meetings in Baranów, the head of the Polish Music Publishing House (PWM) from 1965 to 1988, said that moral choices accompanied every field of the professional activity: "From the very first moment, I regarded the government [of the PPR] as an alien regime. (...) I have always been a positivist, and I think that the positivist spirit (which can be said to be typical of Greater Poland) meant acting here and now, in the present reality, taking advantage of every possible territory of freedom." ${ }^{6}$ Similarly, in an interview to the Polish press in July 1990, Landsbergis justified the social aspect of his professional career choice: "Armed struggle, [postwar] resistance in the forests was over, and a new basis for an honorable life had to be found. (...) Another reason was that nobody invited me to the underground, and I had no contact with the dissident milieu. Just in the same way I had never been in contact with the armed movement before, I was too young. Of course, I knew about that struggle from stories, I knew what it was, but I never really considered participation in the underground activities. Quite a few people of my generation stayed at a distance from the underground. During my studies - and those were the years of

36 Quoted from Krzysztof Droba, Odczytywanie na nowo. Rozmowy z Mieczyławem Tomaszewskim [Re-reading. Conversations with Mieczysław Tomaszewski], Kraków, Akademia Muzyczna w Krakowie, PWM, BOSZ, 2011, 147. 
Stalinism - my worldview was already formed, and I remember explaining to a doctor that, if not armed struggle, the only thing that mattered was positive work, organic activity, however, on an individual scale." ${ }^{37}$ During the political events of the 1980s, most people had to choose whether to move beyond the positivist stance: thus, e.g., after the introduction of the martial law regime in Poland in 1981 through 1983, Polish musicians ignored the public space and for some time did not hold either formal (the Warsaw Autumn) or informal festivals (Musical Meetings in Baranów), while Tadeusz Kaczyński, a mediator in the dissemination of Lithuanian music works, set up an illegally functioning Philharmonic named after Romuald Traugutt. ${ }^{38}$ More than one of the Polish participants of the independent events in question lost their jobs, were spied upon, or otherwise persecuted. ${ }^{39}$ However, from the beginning of the informal cooperation, political attitudes of anti-systemic activity had a greater impact on the commitment of Polish musicians to the development of relationships with their Lithuanian colleagues, greatly enhancing artistic curiosity and the understanding of the cultural mission. Therefore, in 1988, with the formation of the Lithuanian Reform Movement Sajüdis, the promotion of Lithuanian music in Poland inevitably took on a new political dimension, which was widely echoed in the mass and musical press. ${ }^{40}$

\section{The longing for quality communication and new musical identities}

In the mid-1970s, in Poland as well as in Lithuania musical generations changed, and new artistic attitudes were forming. Young Polish composers

37 “O muzyce, która pomaga nie kłamać. Rozmowa z Vytautasem Landsbergisem [About Music Which Helps not to Lie. Conversation with Vytautas Landsbergis]", Ruch muzyczny, 18, 1990, 1, 5.

38 See Filharmonia im. Romualda Traugutta $w$ Warszawie. https://culture.pl/pl/tworca/ filharmonia-im-romualda-traugutta-w-warszawie [viewed on 02. 05. 2018].

39 Upon introduction on the martial law regime, Director of the PWM Publishing House Tomaszewski had to go into hiding for a while. In his letters to Landsbergis, Droba wrote about his close colleagues Andrzej Chłopecki and Małgorzata Gąsiorowska having lost their jobs. Cf. Krzysztof Droba, Odczytywanie na nowo..., op. cit., 160; Krzysztof Droba's letter to Vytautas Landsbergis, Krakow, 08. 04. 1982,Vytautas Landsbergis private archive.

40 In, e.g., interviews of Krzysztof Droba with Vytautas Landsbergis published in the Polish press in 1990. See Krzysztof Droba, Susitikimai su Lietuva [Meetings with Lithuania], Rūta Stanevičiūtè (Ed.), Vilnius, Lietuvos kompozitorių sąjunga, Lietuvos muzikos ir teatro akademija, 2018, 37-47. 
(including "the generation of Stalowa Wola": Andrzej Krzanowski, Eugeniusz Knapik, and Aleksander Lasoń) and musicologists were bored both with the formal musical life and with the Western Second Avant-garde. New spiritual and artistic authorities were looked for: "In the creation of that time, a sharp turn was made towards traditional values which had been ousted out of music circulation by serialism; that was the restitution of expressiveness and emotionality, pushed out by the Second Avant-garde, as integral features of the individual composer language." 41

Using the above-mentioned Bourdieu's concept of the discourse of familiarity, forms of artists' self-organization, based on the communal life principles, emerged, promoting the movement of independent music festivals, meetings, conferences, seminars, etc. in Poland (1975-1989) and Lithuania (since 1985). The festivals organized by Droba in Stalowa Wola (1975-1979), Baranów (1982-1986), and Sandomierz (1988-1989) and the Musical Meetings in Baranów (1976-1981) under the patronage of Tomaszewski brought together several generations of Polish musicians, philosophers, literary people, artists, art historians, architects, and linguists, while only musicians (composers, musicologists, music performers) would come from abroad. The need for quality interpersonal communication ${ }^{42}$ and an intense intellectual discourse brought together spontaneously emerging communities. According to composer Knapik, those events could not last more than several years, because "the intensity, temperature, the heat of meetings with art, and the height of intellectual exchange and interpersonal communication could not be sustained for a longer period of time. Such creative tension cannot last long." ${ }^{43}$ Back in 1977, Zygmunt Mycielski, a Polish composer and music critic of the oldest generation, openly stated the ambition of the meetings: "We have always been looking for what will be said about art (and about us) somewhere else. Darmstadt is already out of fashion, however, there are still Paris IRCAM, Royan, Graz, and so many other places. Isn't it high time that an opinion was born with us - maybe in Baranów?"44

$41 \quad$ Ibid., 189.

42 Interview with Krzysztof Droba, Warsaw, 04. 06. 2017. Droba's arguments make it possible to revise Yurchak's statement that intense personal communication was a special form of social closeness and intersubjectivity in the USSR with an anti-systemic character. Cf. Алексей Юрчак, op. cit., 299.

43 Quoted in Krzysztof Droba, Spotkania z Eugeniuszem Knapikem..., op.cit., 42.

44 Quoted in Vytautas Landsbergis, "Baranovas - dvasia ir apraiškos [Baranów: Spirit and Manifestations]”, in: Geresnès muzikos troškimas, Vilnius, Vaga, 1990, 325. 
When talking about the festivals that became the spaces of independent artistic life, their participants often remembered both the atmosphere of freedom, spontaneity, enthusiasm, and intensity as well as the unusual nature of the events. ${ }^{45}$ The events were also very different from the typical contemporary music festivals in their concert programmes. Although, e.g., one of the incentives of the Stalowa Wola festivals was broader presentation of young composers' works, the programmes included compositions of the $20^{\text {th }}$ century and even of the previous epochs: Polish music from Stanisław Moniuszko to Witold Lutosławski, Arcangelo Corelli, Johann Sebastian Bach, Wolfgang Amadeus Mozart, Johannes Brahms, Richard Strauss, Igor Stravinsky, Alexander Scriabin, and Charles Ives - as well as Mikalojus Konstantinas Čiurlionis and Bronius Kutavičius.

Authorities and sources of creative freedom were sought not merely in the music of one's own generation. Such signposts were also looked for in the then unexpectedly opened Lithuanian music - and the work of Kutavičius became one of them. In 1979, in a monographic Kutavičius' concert in the framework of the $4^{\text {th }}$ MMMM (Młodzi Muzycy Młodemu Miastu ${ }^{46}$ ) Festival, his Sonata for piano (1975), Perpetuum mobile for cello and piano (1979), dedicated to the Festival, First String Quartet (1971), Clocks of the Past for string quartet and guitar (1977), and Two Birds in the Shade of the Woods for voice and instruments (1978) were interpreted by Polish and Lithuanian performers: cellist Kazimierz Pyżik, pianist Halina Kochan, singer Giedre Kaukaite, Vilnius String Quartet, and guitarist Krzysztof Sadłowki. The festival was reviewed by influential critics of Polish music, including current and future members of the Warsaw Autumn Programme Committee Tadeusz Kaczyński and Olgierd Pisarenko, who called Kutavičius the most original Lithuanian composer of the time.

The first performances in Stalowa Wola opened the doors for Lithuanian music and musicians to other non-conformist festivals in Baranów and Sandomierz. Intervening among those were the private music festivals of composer Penderecki in Lusławice - in 1980, the panorama of the new Lithuanian music in them started with Kutavičius' Second String Quartet Anno cum Tettigonia (1980), specially commissioned for the festival, followed by

45 Mieczysław Tomaszewski, "Wspominając [Looking Back]", Teoria muzyki. Studia, interpretacje, dokumentacje. Pismo Akademii Muzycznej w Krakowie, IV/6, 2015, 153.

46 MMMM (Young Musicians for the Young Town) festival in Stalowa Wola (19751979). 
Bajoras' Triptych for voice and piano (1982) and Balakauskas' Spengla-Üla for strings (1984), also commissioned for the festival. Over more than a decade, three generations of Lithuanian composers and performers were introduced to Polish independent contemporary music scenes - from Kutavičius, Bajoras, and Balakauskas to the New Music Ensemble, brought together by Šarunas Nakas, and the works of his contemporaries. It was those events in Poland that made Lithuanian music a phenomenon whose artistic influence was enhanced by the experience of changes in the political reality.

In the discussions of independent music festivals in Poland from a historical distance, their political dimension and strategies for opposing the official cultural discourse had been increasingly emphasised, although at the time, as argued by their organisers and participants, it was not a conscious position just "people who lived at that time looked for a shelter, a place, a milieu in which they could feel free and easy". ${ }^{47}$ The meetings of Polish and Lithuanian musicians were also a cultural confrontation, useful for reviewing the images created by the shared memory of the common state and for defining new musical identities. Before 1989, due to the censorship-imposed restrictions, only a few informative articles on the participation of Lithuanian musicians in independent festivals were published in Lithuania, however, even before the political changes, the feedback of Polish music criticism spread in Lithuania in informal ways as the echoes of international recognition and appreciation of Lithuanian music. The performances of Kutavičius' compositions, and especially his oratorios, at the Warsaw Autumn $(1983,1990)$ and Collectanea (1988) festivals inspired a sharp shift in the reception of Lithuanian music, from "unknown" to "exotic". Although different, the epithets 'unknown' and 'exotic' enabled Polish music critics to define through music a new Lithuanian cultural identity, far removed from previous politicised stereotypes. According to Lisa Jakelski, that was influenced by a revision of Polish-Lithuanian relationships among Polish intellectuals in the 1970s and 1980s: "Czesław Miłosz was rediscovered; independent press articles began defining Belarussians, Lithuanians, and Ukrainians not as enemies, but as brothers that Poland had

47 "Dar od losu. Krzysztof Droba w rozmowie z Kingą Kiwalą", Teoria muzyki..., op. cit., 118,124 . The strategies of political opposition were more frequently emphasised in the works of foreign reseachers, see, e.g. Cindy Bylander, "Charles Ives i festiwal w Stalowej Woli. Inspiracje i spuścizna [Charles Ives and the Festival in Stalowa Wola. Inspirations and Legacy]", Teoria muzyki..., op. cit., 95-116. 
to support in their struggle for national self-determination." 48 According to Jakelski, the Polish music critic who interpreted the oratorios by Kutavičius was filled with sentiments to a history of Lithuania published by Polish independent publishers in 1984: "We must forget the common trauma and no longer regard Lithuania as part of Poland. Every nation has the right to independent life, therefore, if we are to become a sovereign and free nation, we must respect the aspirations of independence of the people we are related to through historical and cultural bonds." 49

Resistance to the official discourse and the imposed political and cultural regime enabled Polish and Lithuanian musicologists to get to know each other and to engage in a more active dialogue in the late 1980s. It is symptomatic that, in the years of political changes, conferences of Lithuanian and Polish musicologists were first organized: in 1989, the first one was held in Vilnius by the musicologist sections of the Lithuanian and Polish Composers' Unions. Although in that year the Lithuanian Composers' Union declared its separation from the central organization of the USSR, the Polish colleagues who undertook the initiative had to obtain permission from the USSR Composers' Union for a joint event in Lithuania. Delegated by the Polish Composers' Union to Moscow, Droba recalled spending a week in Moscow persuading USSR music functionaries of the benefits of contacts between the "fraternal countries". ${ }^{00}$ The Polish Composers' Union did not participate in the organization of the conference and just paid a honorarium (PLN 125,000) to the coordinator of the Polish participants, ${ }^{51}$ which were rapidly devalued by inflation. The topic chosen for the 1989 conference in Vilnius - The Music of the Late $20^{\text {th }}$ Century in the Eyes of Lithuanians and Poles - brought together active participants of the festivals and meetings in Stalowa Wola, Baranów, and Sandomierz, providing the milieu of musicians, born of informal rela-

\footnotetext{
48 Lisa Jakelski, "The Polish Connection: Lithuanian Music and the Warsaw Autumn Festival”, in: Agnieszka Pasieka, Paweł Rodak (Eds), \#Polishness. Rethinking Modern Polish Identity. (Forthcoming).

49 Ibid.

50 Krzysztof Droba, "Ku pamięci [In Memory]", in: X Polsko-Litewska Konferencja Muzykologyczna. 14-16 grudnia 2006. Program, Kraków, Akademia Muzyczna w Krakowie, 2006, 5.

51 In 1989, due to the inflation in Poland, over the several months of the conference organization, the exchange rate of the Polish currency fell several times: in March 1989, 1 USD cost 3,000 zloty, while in June, it was already 8,000 zloty. The seemingly impressive honorarium was worth 25 USD. See http://pl.wikipedia.org/wiki/1989.
} 
tionships, with a stimulus for the renewal and improvement of transnational cultural exchanges. The thematic guidelines of the annual conferences, taking place alternately in a different country, were matured at the meetings and conferences of independent festivals: common cultural memory and heritage and new Lithuanian and Polish music in cultural and political contexts. ${ }^{52}$

\section{Conclusion}

The informal relationships between the musicians of the two neighbouring countries, analysed in the article, opposed the sham internationalism and official musical export carried out by the central institutions of the USSR and the Polish People's Republic through their hierarchical channels. The pursuit of keeping distance from the official centre and the musical phenomena promoted by it predetermined the location of the informal contemporary music scene in both Poland and Lithuania: musicians were getting together off the censored culture centres and forming communities thirsty for intense and high quality artistic communication in cultural peripheries. Thus, during the Cold War period, informal contacts between Lithuanian and Polish musicians developed into effective networking. In the Lithuanian music culture of that time, it was an exclusive communion, formed by overcoming long-standing political stereotypes and being able to recognize the difference and otherness of a close neighbour's culture.

Padraic Kenney's analytical approach, adapted to the analysis of the Lithuanian-Polish musical cooperation, revealed that, just like in political and social movements, the effectiveness of networking in cultural domains was predetermined by its contribution to social and cultural transformation. Not only the transnational migration of ideas and artistic phenomena, but also the synergistic potential of different cultural perspectives was important in that case. The informal networking of Lithuanian and Polish musicians highlighted the transnational competences of both milieus necessary to understand the practices and values of the other culture as well as the political and national self-image. As a result, at the end of the Cold War, the relationship between Polish and Lithuanian musicians was accompanied by intercultural empathy as well as a deep interest in, and respect for, the traditions and ex-

52 Over the period of 1989-2010, ten conferences of Lithuanian and Polish musicologists were held in Vilnius, Krakow, and Łódź. The programmes of the conferences were published in: Krzysztof Droba, Susitikimai su Lietuva..., op. cit., 235-256. 
periences of the other - and a very different - culture..$^{53}$ The discussed processes took place in the context of the political transformations of the bloc of the communist countries, and although they were not inspired by any specific events of political history, the political and social commitment of musicians was evident, while some activists of the Lithuanian and Polish musical networks joined the political movements. However, in this case, it is not possible to speak of absolute synchronisation of political and cultural history, which is confirmed not only by the origins of the phenomenon in question but also by the ebb of cooperation between Lithuanian and Polish musicians in the 21st century, having nothing in common with any specific political impulses.

\section{Works cited}

"A zaczeło się - od Festiwali w Stalowej Woli. Z Krzysztofem Drobą rozmawia Alwida Rolska [It Began from the Festival in Stalowa Wola. Alwida Rolska Interviews Krzysztof Droba]", Kurier Wileński, 27. 11. 1990.

Bourdieu, Pierre: Outline of a Theory of Practice. Cambridge: Cambridge University Press, 1977.

Bylander, Cindy: "Charles Ives i festiwal w Stalowej Woli. Inspiracje i spuścizna [Charles Ives and the Festival in Stalowa Wola. Inspirations and Legacy]", Teoria muzyki. Studia, interpretacje, dokumentacje. Pismo Akademii Muzycznej w Krakowie, IV/6, 2015, 95-116.

"Dar od losu. Krzysztof Droba w rozmowie z Kingą Kiwalą [Gift of Fortune. Kinga Kiwala Interviews Krzysztof Droba]", Teoria muzyki. Studia, interpretacje, dokumentacje. Pismo Akademii Muzycznej w Krakowie, IV/6, 2015, 117-138.

Droba, Krzysztof: Susitikimai su Lietuva [Meetings with Lithuania], Rūta Stanevičiūtè (Ed.). Vilnius: Lietuvos kompozitorių sajunga, Lietuvos muzikos ir teatro akademija, 2018.

Droba, Krzysztof: Odczytywanie na nowo. Rozmowy z Mieczyławem Tomaszewskim [Re-reading. Conversations with Mieczysław Tomaszewski]. Kraków: Akademia Muzyczna w Krakowie, PWM, BOSZ, 2011.

Droba, Krzysztof: Spotkania z Eugeniuszem Knapikem [Meetings with Eugeniusz Knapik]. Katowice: Akademia Muzyczna im. Karola Szymanowskiego w Katowicach, 2011.

Droba, Krzysztof: "Ku pamięci [In Memory]”, in: X Polsko-Litewska Konferencja Muzykologyczna. 14-16 grudnia 2006. Program. Kraków: Akademia Muzyczna w Krakowie, 2006, 5.

Droba, Krzysztof: "Z myślą o przyszłej Jesieni [With a View to Future Autumn]”, Ruch muzyczny, 25, 1975, 13-15.

53 Cf. Vertovec, op. cit., 70. 
Hakobian, Levon: “The Reception of Soviet Music in the West: a History of Sympathy and Misunderstanding", Musicology, 13, 2012, 125-137.

Jakelski, Lisa: “The Polish Connection: Lithuanian Music and the Warsaw Autumn Festival", in: Agnieszka Pasieka, Paweł Rodak (Eds), \#Polishness. Rethinking Modern Polish Identity (Forthcoming).

Katkus, Donatas: "Vilnius groja Afrikai [Vilnius Plays for Africa]", Gimtasis kraštas, 10. 02.1977.

Kenney, Padraic: "Opposition Networks and Transnational Diffusion in the Revolutions of 1989”, in: Padraic Kenney, Gerd-Rainer Horn (Eds), Transnational Moments of Change: Europe 1945, 1968, 1989. Lanham, MD: Rowman \& Littlefield, 2004, 207-223.

Kuprevičius, Giedrius: “Jaunųjų kūrybos pasiklausius [Upon Listening to Compostions of the Youth]", Kauno tiesa, 26. 03. 1977.

Landsbergis, Vytautas: Geresnès muzikos troškimas [The Desire for Better Music]. Vilnius: Vaga, 1990.

Mikkonen, Simo, Koivunen, Pia (Eds): Beyond the Divide. Entangled Histories of Cold War Europe. New York, Oxford: Berghahn, 2015.

Mulevičiūtè, Jolita: “Atsinaujinimo sąjūdis lietuvių tapyboje 1956-1970 m. [Renewal Movement in Lithuanian Painting in 1956-1970]", in: Žmogus ir aplinka XX a. Lietuvos daileje. Vilnius: Academia, 1992, 128-199.

Nakas, Šarūnas: "Kelionè be kelio, nes veidrodis be atspindžio [Travel with no Road, because of the Mirror without Reflection]". Access online: http://www.modus-radio. com/eseistika/kelione-be-kelio [viewed on 05. 06. 2019].

"O muzyce, która pomaga nie klamać. Rozmowa z Vytautasem Landsbergisem [About Music Which Helps not to Lie. Conversation with Vytautas Landsbergis]", Ruch muzyczny, 18, 1990, 1, 5.

Ramonaite, Ainè (Ed.): Nematoma sovietmečio visuomene [The Invisible Society of the Soviet Era]. Vilnius: Naujasis židinys-Aidai, 2015.

Naktinyte, Rūta: “Inertiškumo simptomai? [Symptoms of Inertia?]”, Literatūra ir menas, 30. 11. 1974.

Schmelz, Peter J.: "Intimate Histories of the Musical Cold War: Fred Prieberg and Igor Blazhkov's Unofficial Diplomacy”, in: Jessica C. E. Gienow-Hecht (Ed.), Music and International History in the Twentieth Century. New York: Berghahn, 2015, 189-225.

Schmelz, Peter J.: Such Freedom, If Only Musical: Unofficial Soviet Music during the Thaw. Oxford: Oxford University Press, 2009.

Schmelz, Peter J.: “What Was 'Shostakovich', and What Came Next?", Journal of Musicology, 24/3, 2007, 301-303.

Tomaszewski, Mieczysław, "Wspominając [Looking Back]”, Teoria muzyki. Studia, interpretacje, dokumentacje. Pismo Akademii Muzycznej w Krakowie, IV/6, 2015, 153-155.

Vertovec, Steven: Transnationalism. London and New York: Routledge, 2009. 
Yurchak, Alexei: Everything Was Forever, Until It Was No More. The Last Soviet Generation. Princeton and Oxford: Princeton University Press, 2006.

Чередниченко, Татьяна: Музыкальный запас. 70-е. Проблемы. Портреты. Случаи

[Musical Resources. The 1970s. Problems. Portraits. Cases]. Москва: Новое литературное обозрение, 2002.

Юрчак, Алексей: Это бьло навсегда, пока не кончилось. Последнее советское поколение. Москва: Новое литературное обозрение, 2014.

\section{Summary}

During different stages of the Cold War, the communication and collaboration of Polish and Lithuanian musicians were of various levels of intensity and rather controversial. For a long period of time, Lithuanian music spread through Poland only via vertical channels, as part of the USSR's foreign cultural (and economic) policies - in the international activities of influential Soviet institutions, such as Goskoncert, the official state concert agency of the USSR, and the USSR Composers' Union. The limitations and constraints imposed by the centralized music exports were circumvented due to the special role of Poland on the contemporary musical scene both in the Communist world and in the ideologized East-West confrontation. However, the breakthrough in the dissemination of Lithuanian and Polish music and its transnational cultural understanding in Poland and Lithuania occurred not because of the liberalization of political constraints or the strengthening of the economic leverage through the vertical (centralized institutions) and horizontal (national organizations) channels, but due to the forging of informal relations between the unofficial Polish stage of contemporary music and the institutionally independent actions of Lithuanian composers and musicologists since mid-1970s. That promoted the full-value representation of the works of Lithuanian composers on the official stages of Poland, which formed an internationally influential Polish critical discourse on Lithuanian modern music. In both Poland and Lithuania, independent music festivals, artistic actions, private lectures and semi-official publications (samizdat/magnitizdat) flourished on the margins of official culture as cultural expression of liberation. From oppositional to mainstream culture festivals in Stalowa Wola, Baranów, Sandomierz, cultural activism during Martial Law such as the Traugutt Philharmonic (Poland), privately grounded youth music festivals in Druskininkai, Anykščiai, Kaunas and Vilnius, underground Fluxus movement (Lithuania) to Baltic Singing Revolution - all these cultural events and activities demonstrate the rupture between the attempts of authorities to maintain a total institutional control and the distrust of the society in it, the emancipative needs of individual. In that particular environment, a new view on Lithuanian culture was shaping in Poland, which allowed Polish critics through music to define a new Lithuanian cultural identity, different from the previous politicised stereotypes, while the Polish music and musicology contributed to the renewal of the music modernisation discourse in Lithuania. 